\title{
洪水規模の違いによる便益の地域差に関する研究 〜メコン河プノンペン周辺における事例解析〜
} THE REGIONAL DIFFERENCE OF THE BENEFIT WITH THE FLOOD MAGNITUDE CHANGE

$\sim$ CASE STUDY IN THE GREATER PHNOM PENH OF THE MEKONG RIVER

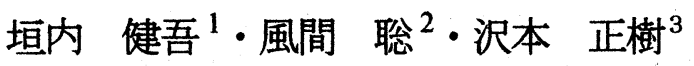

Kengo KAKIUCHI, So KAZAMA, Masaki SAWAMOTO

\author{
1学生員 東北大学大学院工学研究科土木工学専攻 (广980-8579 仙台市青葉区荒巻字青葉06) \\ ${ }^{2}$ 正会員 博士(工学) 東北大学大学院噮境科学研究科棵境科学専攻（广980-8579 仙台市青葉区荒巻字青葉 04) \\ ${ }^{3}$ フェロー 工博 東北大学大学院工学研究科土木工学尃政（广980-8579 仙台市青葉区荒巻字青葉06)
}

This paper shows spatial distribution of merits and demerits of flood in the Mekong Basin. Firstly, the flood and inundation surrounding Phnom Penh, Cambodia in 2000 (the large flood) and 1994 (the normal flood), was simulated. Secondly, the benefits of the flood were calculated, combining the unit price of primary industry (agriculture and fishery) and the result of the flood simulation. As a result, the large flood gives high productivity of rice along rivers because it flowed out nutrition a lot. It also expanded fish product area in the flood plain. Therefore, agriculture and fishery obtained higher benefits in 2000 than 1994. The spatio-temporal benefits and damages were constructed.

Key words: Colmatage, unit price, flood simulation, GIS, damage

\section{1.はじめに}

2000 年のメコン河洪水氾濫では, カンボジア国内だけ で 20 万人近い人が避難し儀牲者は約 400 人にも上った. その他儀牲者はベトナムで 200 人近く, タイとラオスで は 50 人近く報告されている.この洪水の規模は既往最大 のものに近いとされている.

この洪水に対し, 土木学会から調査団が派遣され, 現 地調查と情報収集が行われた ${ }^{1)}$. その報告書の中では, 洪水氾濫に対する都市部と地方の認識の差が指摘された. 都市域では流通や教育の停滞からその被害の深刻さが指 摘されていたが，地方部では自然と受け止め，生産の場 として洪水を利用していた. 元来洪水は負のイメージで あるが，近年，正の部分も着目されつつある. 特にメコ 之河の場合, 洪水の規模と水産資源の相関は高く ${ }^{2)}$, 汇濫 水が引いた後には肥沃な土壤が残る，洪水は肥沃な土壤 と水産資源をもたらすものであり，居住者は洪水に対す る危機意識が低い。

こうした問題を包括的に論じるために，教育や産業の 評価が定量的に扱われる必要があり，かつ相互比較でき るものである必要がある. そこで, 風間ら ${ }^{31}$ は洪水の変 動に伴う影響を価格価值に置き換える便益手法を導入し
て洪水汇濫を総合的に評価することを試みている.

洪水に対する便益計算は国内ですでに多くの事例があ り, 治水経済調査マニュアルとして作成されている ${ }^{4)}$. また,カンボジア政府は 2000 年洪水による被害額を報告 している ${ }^{1)}$ 。こうした報告書では，便益や損害が対象地 域内において一括で計算され，州スケールでの算定はな されているが, それでは局所的な把握ができない.また， カンボジアにおいては, 被㝬時期に関しても不明膫な点 が多く, 時系列での考察が行えない.

本研究では, まずメコン河, バサック川およびトンレ サップ川の洪水氾濫シミュレーションを $1 \mathrm{~km}$ メッシュ 区画で行った. その結果として, 時系列かつ分布的に水 位が得られる. 時空間を考慮したこの結果は, メッシュ 区画の便益計算を行うのに適したものだといえる.一般 的な規模の洪水であった 1994 年と大洪水の起きた 2000 年を対象としてプノンペン周辺の洪水氾濫の数值計算を 行い，その結果に便益の原単位 ${ }^{3)}$ を組み合わせることか ら氾濫による影響を定量化した。

メコン河下流域の氾濫の規模は大きく，コスト面から も効果的な治水事業が望まれる. 汇監の与える各影響を メッシュ区画に同じ指標である便益で評価することで, 洪水氾濫の生かすべき箇所と防ぐ必要のある地域の理解 が可能になると考えられる. 上で述べた評価法は開発政 
策の意志決定の支援ツールとして期待できるものである.

\section{2. データ}

評価対象地域（図 1）は，カンボジア国首都プノンペ ンをほぼ中心とした $110 \mathrm{~km} \times 140 \mathrm{~km}$ の $15,400 \mathrm{~km}^{2}$ である. 数值計算のデータとして以下のものを用意した. 地理情 報として標高データにUSGS の GTOPO30を用いた. 水 位およびSSはメコン河委員会が編集したデーダ)を利用 した. SS は, 氾濫原における栄養塩量を考虑する際に用 いた.

\section{3. モデル}

\section{（1）洪水流社算}

河道の流れは流下方向の一次元で計算を行う. 本研究 では一次元の Dynamic Wave モデルを用いた. 本モデル は本研究の対象領域のような, 河床勾配の非常に緩い河 川の洪水追跡に適している. 以下の連続式と運動方程式 から成っている.

$$
\begin{aligned}
& \frac{\partial A}{\partial t}+\frac{\partial Q}{\partial s}-q=0 \\
& \frac{1}{g} \frac{\partial v}{\partial t}+\frac{1}{2 g} \frac{\partial v^{2}}{\partial s}+\frac{\partial H}{\partial s}+\frac{n^{2}|v| v}{h^{4 / 3}}=0
\end{aligned}
$$

ここで, $A:$ 断面櫝 $\left(\mathrm{m}^{2}\right), Q:$ 流量 $\left(\mathrm{m}^{3} / \mathrm{s}\right), \quad s:$ 流下方向の 座標, $g$ : 重力加速度, $v$; 流速 $(\mathrm{m} / \mathrm{s}), H$ : 基準面からの 水位 (=水深+河床高), $n$ : マニングの粗度俰数, $h:$ 水

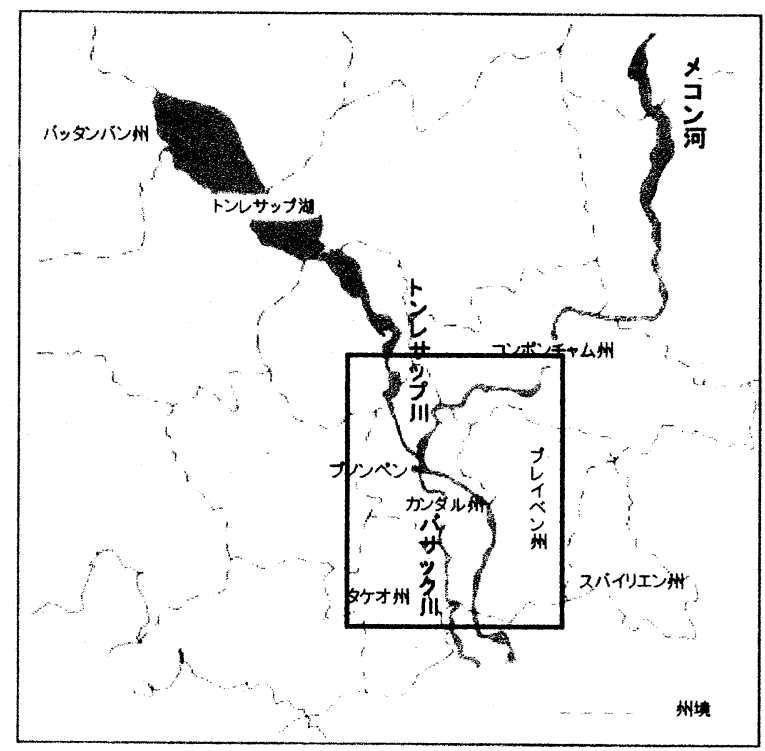

図-1 評価対象地域（枠内）
深を表している. $q$ は横流入量 $\left(\mathrm{m}^{2} / \mathrm{s}\right)$ であり，他の川から の流入や，雨による流入が該当する. 流出する場合は符 号が逆になる.

\section{（2）氾澏流胡篎}

氾濫原の計算には二次元不定流モデルを用いた。 本モ デルは本対象領城のように勾配の緩い地形に適しており， 河道から溢れた水が氾監原を二次元的に広がっていく様 子を計算するものである.

$$
\frac{\partial h}{\partial t}+\frac{\partial M}{\partial x}+\frac{\partial N}{\partial y}=q
$$

$$
\begin{aligned}
& \frac{\partial M}{\partial t}=-g h \frac{\partial H}{\partial x}-\frac{g n^{2} M \sqrt{M^{2}+N^{2}}}{h^{7 / 3}} \\
& \frac{\partial N}{\partial t}=-g h \frac{\partial H}{\partial x}-\frac{g n^{2} N \sqrt{M^{2}+N^{2}}}{h^{7 / 3}}
\end{aligned}
$$

ここで, $M, N$ は東西方向, 南北方向の流量フラックス $\left(\mathrm{m}^{2} / \mathrm{s}\right)$ を表し $, M=u h, N=v h$ である. $q$ は鉛直方向の流入 量 $(\mathrm{m} / \mathrm{s})$ で, 降雨や蒸発が該当する.

式(4)，(5)は本来移流を表す非線形項を含んでいるが, 流れの変化が緩、場合にはこの項の影響は小さいことが 知られている. また，計算が長く複雑になることと，本 研究の目的が局所的な氾濫流の到達時間や浸水深の蕨密 な解析ではなく，氾濫域のおおよその範囲を求めること にあるため, 非線形項は省略した。

\section{（3）越流浢算}

本研究の対象流域ではコルマタージュ(写真 1)と呼ば れる灌涀方法が行われており, 堤防の一部を開き, 洪水 を汇濫原に引き入れて農業用水として用いている，堤防 の開かれた筒所を参考に汇濫原へ越水する流量は，次の 越流公式を用いて求める.

完全越流の場合

$$
Q=0.35 B h_{1} \sqrt{2 g h_{1}}
$$

\section{もぐり越流の場合}

$$
Q=0.95 B h_{2} \sqrt{2 g\left(h_{1}-h_{2}\right)}
$$

ここで, $B$ は越水幅で, 越水部において敷高からみて高 いほうの水深が $h_{l}$, 低いほうの水深が $h_{2}$ である.

このモデルで得られた越流量は，隣接する氾濫原への 流入となり，氾濫計算に加えられると同時に，洪水計算 の連続式における横流出量となる。

図 2 は, これらの計算方法を用いて 2000 年と 1994 年 
の8月 1 日での水深をシミュレートしたものである．氾 濫面積に大きな差があることをよく示せている.

\section{（4）SS 沈降旦の計算}

SS データと Rubey の実験式から得た沈降速度, 不定流 式の流量フラックスから氾濫原への SS 沈降量を求め, この值から栄荃塩量を推定した。

Rubey の実験式は欣式である.

$w_{f}=\sqrt{s g d}\left\{\sqrt{\frac{2}{3}+\frac{36 v^{2}}{s g d^{3}}}-\sqrt{\frac{36 v^{2}}{s g d^{3}}}\right\}$

ここで, $w_{f}$ : 浮遊砂の沈降速度 $(\mathrm{m} / \mathrm{s}), v$ : 水の動粘性係 数 $=1.0 \times 10^{-6}\left(\mathrm{~m}^{2} / \mathrm{s}\right), s:$ 砂粒の水中比重, $d:$ 粒径 $(\mathrm{m})$ を 表している.

また, プノンペンのバサック川沿いで採取した砂で試 験を行った. その結果, 砂粒の水中比重は 1.667 , 粒径は 図3のように求められた。通過百分率 $20 \%, 50 \%, 80 \%$

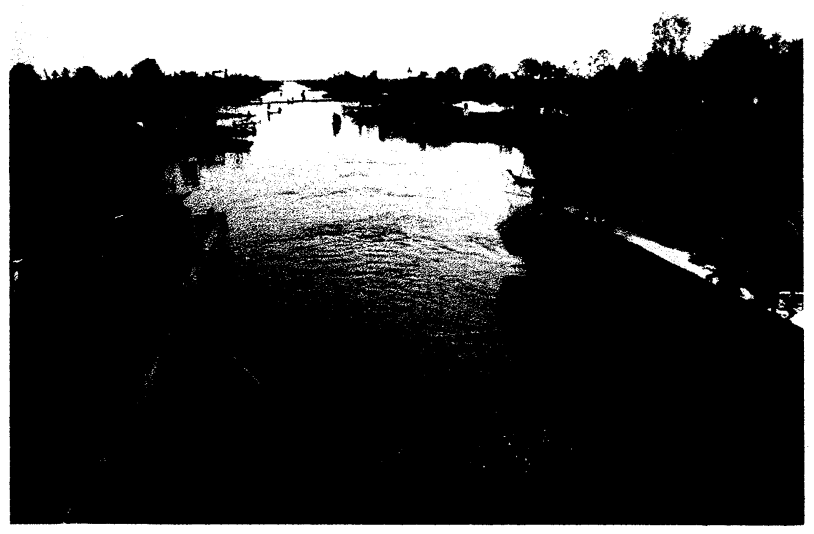

写共-1 コルマタージュからの導水

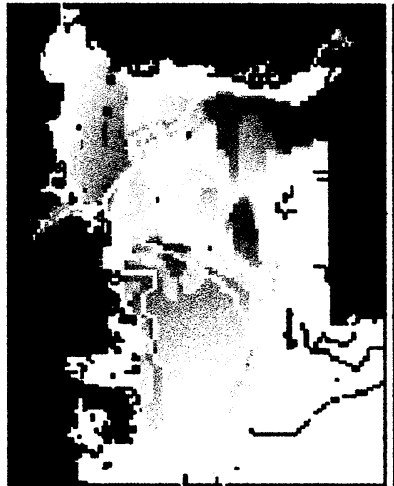

2000 年 8 月 1 日

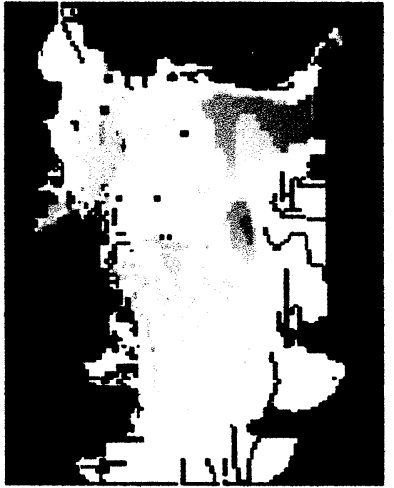

1994 年 8 月 1 日 (m)
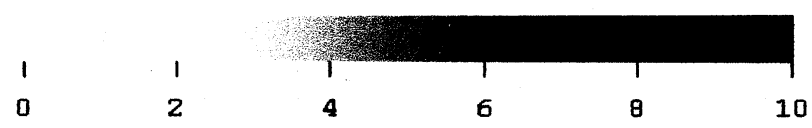

罒-2 氾濫面積と水深の比較
において沈降速度を求め, $\Delta t$ ごとの沈降量を計算し，そ れを積算して, 沈降量の総量を算出した.

表 1 は, 2000 年と 1994 年の堆砂面積を表したもので ある. 粒径が大きいほど遠くまで広がらず, 川沿いに堆 積することが分かる. 比較的粒度の荒い泥はメコン河本 流やバサック川の河岸に沈殿し自然堤防を形成するため, 後背湿地には粒度の細かい粘土分を多く含んだものが沈 殿する \%.したがって, 本研究では, 粒径が小さい通過 百分率 $80 \%$ \%SS 沈降量を栄養塩量の指標として用いた.

図 4 は通過百分率 $80 \%$ でのSS 沈降量である. 2000 年 の氾濫原の方が多くの栄羑塩を得ていることが分かる.

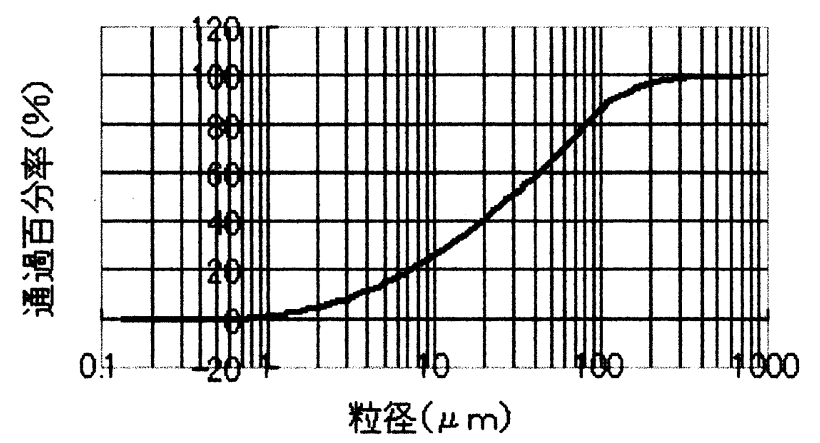

図-3 メコン河における浮遊砂の粒度分布

表-1 2000 年と 1994 年における粒径と堆砂面積の比較

\begin{tabular}{|c|c|c|c|}
\hline & 粒径 $(\mu \mathrm{m})$ & $\begin{array}{c}2000 \text { 年の } \\
\text { 堆砂面積 } \\
\left(\mathrm{km}^{2}\right)\end{array}$ & $\begin{array}{c}1994 \text { 年の } \\
\text { 堆砂面積 } \\
\left(\mathrm{km}^{2}\right)\end{array}$ \\
\hline 通過百分率 $20 \%$ & 81.0 & 2351 & 2016 \\
\hline 通過百分率 $50 \%$ & 28.0 & 5015 & 3991 \\
\hline 通過百分率 $80 \%$ & 7.1 & 7739 & 6869 \\
\hline
\end{tabular}

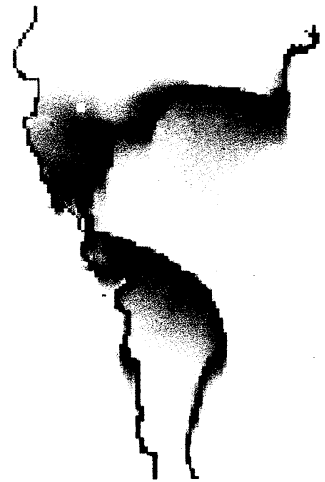

2000 年

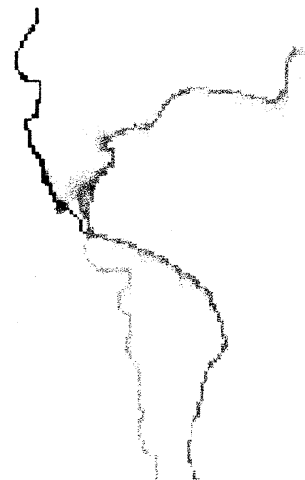

1994 年 $\left(\mathrm{kg} / \mathrm{m}^{2}\right)$

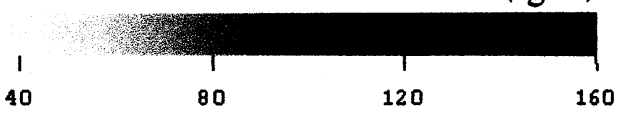

因-4通過百分率 $80 \%$ 粒径での SS 沈降量 


\section{4. 漁菜への影羉}

一般に，雨季の訪れと共に魚の逆上・産卵が本格化す るわと言われる. 冠水する間に，汇濫原で魚が産卵する ことにより便益が生じる.

本研究では, 雨季初期の 5 月から 7 月(約 90 日間)が産 卵期であるとした. 洪水氾濫計算より，2000 年と 1994 年で, 産卵期中での湛水継続期間（冠水している日数） ごとに汇濫面積を求めた結果, 図 5 のようになった。

また，対象地域内での魚類の約 $42 \%$ は触科である ${ }^{8}$. 鯉科は産卵期に2, 3 回産卵寸ると言われる. 鯉科の産卵 周期が約 20 日であることから,20 日以内の湛水継続期間 では産卯は行えないものと仮定し, 水産業の便益を0円 とした.

風間らによると，水産物の原単位は 1 年当たり 1,200,000 円 $/ \mathrm{km}^{2}$ である ${ }^{3)}$.この原単位は, 氾濫原の単位 面積あたりの平均便益である. よって，この原単位と図 5 から, 次式を用いて, 1 日あたりの湛水で得られる便益 を求められる.

$$
\sum_{n=21}^{90}\left\{x \times(n-20) \times A_{n}\right\} / \sum_{n=21}^{90} A_{n}=1200000
$$

ここで， $\mathrm{x}: 1$ 日湛水便益(円), $n:$ 湛水継続期間(日), $A_{n}$ : 湛水継続期間が $n$ (日)のときの汇濫面櫝 $\left(\mathrm{km}^{2}\right)$ である.

この式から $x$ を求めると, 2000 年が 98000 円に対して 1994 年は82000 円と低くなった。 理由としては, 図5 ら得られた 21〜25 日の湛水継続期間での氾濫面積に大 きな差があることが挙げられる. 図6は， $x$ と湛水継続 期間を乗算し，メッシュ区画で漁業の便益計算をしたも のである. 漁業においては 2000 年の便益のほうが大きく なるという結果を得た（表2).

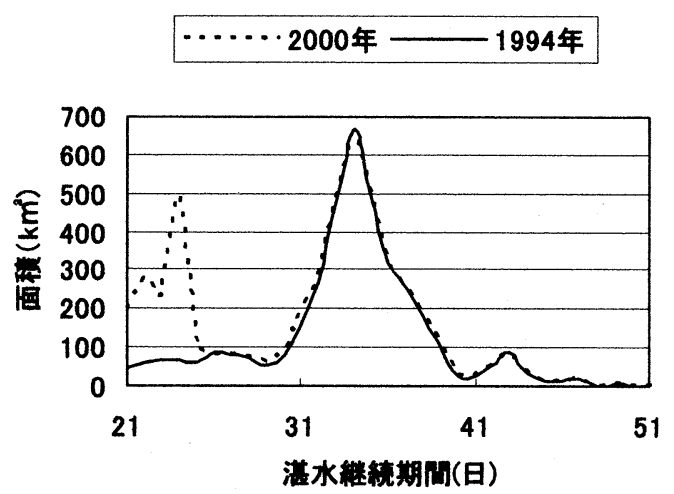

因-5 産卯期中の湛水継続期間に対する氾濫面積

\section{5. 莀莱への影笋 \\ （1）便益計算}

氾濫水を利用する農業とは，一般的に第 2 期農業（11 月〜1 月）のことである. 汇濫による栄養塩と水を利用 して高収穫米を栽培する. 本研究では, 氾濫水の確保が 可能である総沫濫域で水田が可能であるとした.

次に, 肥料と考えられる窒素堆積量と収量の関係を線 形と仮定した. 高収權米の最適窒素量を $0.014 \mathrm{~kg} / \mathrm{m}^{2}$ 以上 とし9)，その地域での便益を 4,968,000 円 ${ }^{3)}$ とし。.この 数値は, 高収穫米の原単位である. 一方で, 沈降量が 0 $\mathrm{kg} / \mathrm{m}^{2}$ である場合は，栄養塩の提供がないものとし，便 益には，最も収穫量が低いとされる浮稲の原単位を用い た.

SS に付着する窒素量は，メコン河委員会のデータ ${ }^{5)}$ より求めた結果, SS 沈降量の 200 分の 1 とし, これは片 山の日本での研究から得た值 ${ }^{10)}$ とほぼ同じである. 最適 窒素量を上回る栄養塩が得られる地域は最大便益である という仮定のもと, 便益計算を行った.

図 7 は 2000 年および 1994 年の農業の便益計算をした ものである. 農業の便益は河沿いが高くなり，遠ざかる につれて減少する. 栄養塩の多くが河沿いに沈降するた めである. 農業においては,1994 年よりも大洪水が起こっ た 2000 年の便益が大きくなるという結果を得た(表2).
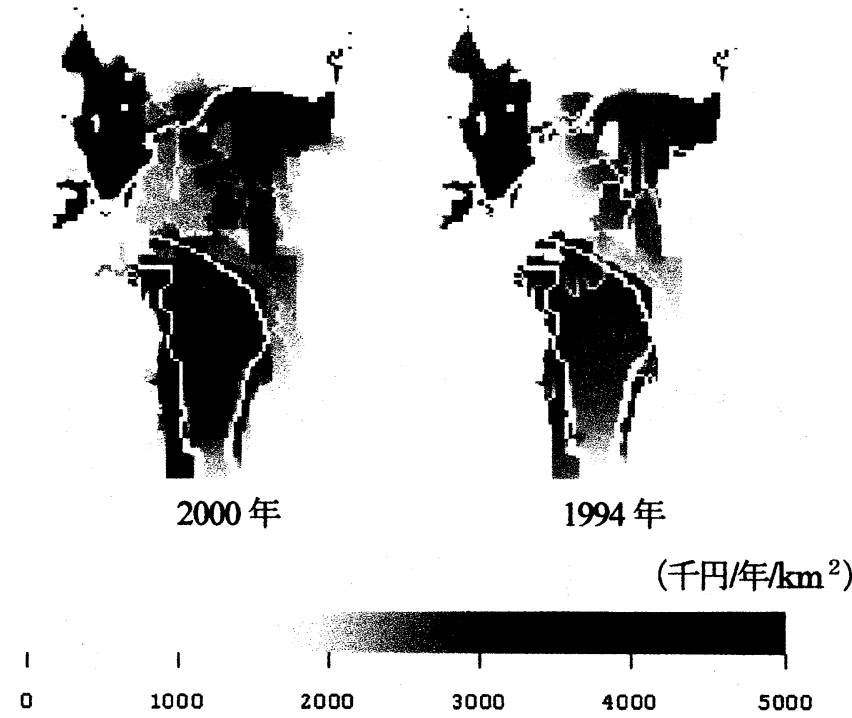

图-6一年当たりの漁業の便益

衰-2 評価対象地域での便益と損害

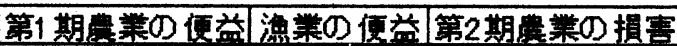

\begin{tabular}{|c|c|c|c|}
\hline 2000年 & 383.5儇円 & 199.91䍚円 & 108.6僡円 \\
\hline 94 年 & 351.7 信円 & 139.31僡円 & - \\
\hline
\end{tabular}




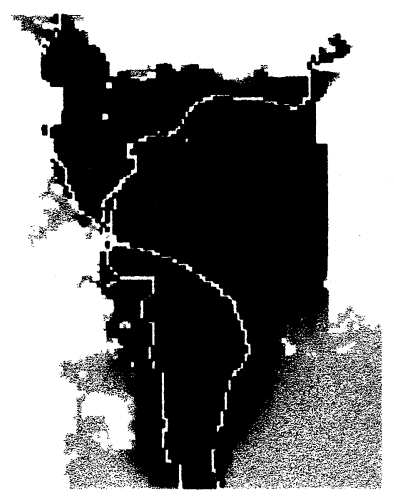

2000 年

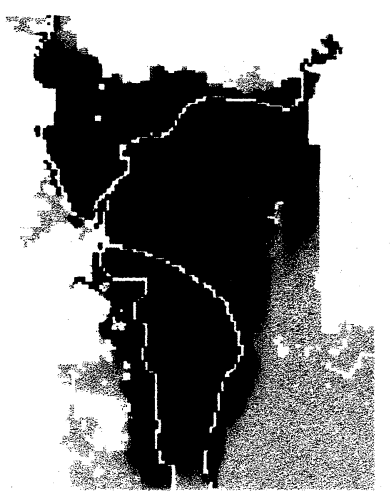

1994 年

(千円/年 $\left./ \mathrm{km}^{2}\right)$

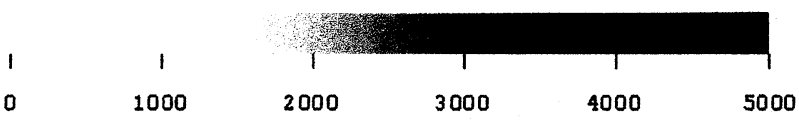

図-7一年当たりの農業の便益

\section{（2）損害㖕算}

雨季は 5 月頃から始まる，その降雨を利用して栽培さ れる第 1 期農業（6月～8月）は，2000年に大不作に陥 った. その要因として，例年よりもはるかに早く洪水が 発生したことが挙げられている. 収穫前に氾濫が来た高 収權米地帯では多大な損害を受けた。本研究では, 收穫 前 8 月 1 日の 1994 年と 2000 年の洪水汇濫を比較するこ とで高收穫米の椇害を示した.

図 2 より 2000 年と 1994 年の 8 月 1 日の氾濫状況を比 較すると, 氾濫面積は 1994 年が $7019 \mathrm{~km}^{2}$ に対して 2000 年が $8953 \mathrm{~km}^{2}$ と約 1.3 倍大きい. また全般的に 2000 年の 水位の方が高い. 大洪水が起きた理由としては, 中・上流 域で例年よりも早く雨季が始まったことが挙げられる ${ }^{1)}$. 高收穫米は浅水に保たれる所で栽培される ${ }^{11)} .1994$ 年 では冠水しない地域で, 2000 年の洪水で収穫前に $30 \mathrm{~cm}$ 以上氾濫した地域では損害を受けたとしている.

\section{6. 考察 \\ （1）栄黄塩について}

図4において，河から遠ざかるにつれて， Ss 沈降量が 減少するのは明白なことである. しかしながら, 河から 遠いはずのプレイベン上部付近で多くの栄盖塩量が堆積 しているという計算結果が得られた. 理由としては, こ の地域では早くに氾濫し，また氾濫するときの流量が多 いために，湛水継続期間が長くなることがあげられる.

特に, 2000 年の結果では, コンポンチャム州からプレイ ベン州（図 1) にがて, 広範囲にわたって栄養塩が供 給されていることが分かる.

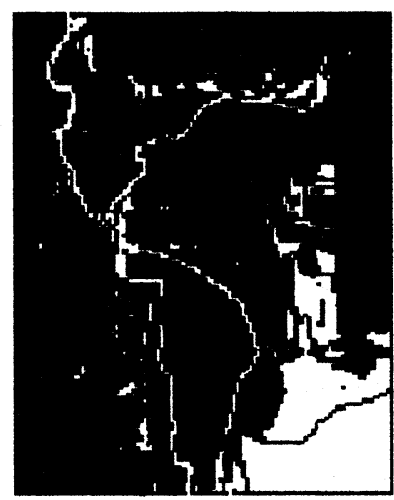

黒色 $-0, \quad$ 白色 -4980 (河道は除く）

(千口/年 $/ \mathrm{km}^{2}$ )

因-8 2000年における農業の損害額

\section{（2）漁莱について}

図 5 より，湛水継続期間が 21 日〜25 日である氾濫面 積の差が大きい. このことが, 2000 年と 1994 年での便 益の大きな差となっていると考えられる.

一方で, 湛水継続期間が 25 日以後の氾濫面積では, 2000 年と 1994 年は良く酷似している.このことから， 大洪水が起きることに対して，あまり影響を受けない地 域が広く存在することも，この結果から理解できる.

図6では, プレイベン州やタケオ州といった，川から 離れた地点での便益に大きな差が現れた. そのような地 域は，湛水継続期間が 21 日〜25 日となる氾濫地域であ り, 大洪水が起きない限りは魚が産卵を行うことが出来 ない地域だとも言える.

対象地域内での魚の生態については未知な点が多い. したがって, 今回は魚の生息·産卵条件に, 浸水深との関 倸は加えなかった。

\section{（3）農業について}

図7において, プレイベン州上部およびカンダル州下 部で, 2000 年が高い便益を得た. 理由としては, コンポ ンチャム州からプレイベン州にかけての栄養塩量の差が, そのまま便益にも顕著に現れていることが挙げられる. また, 総氾濫面積は 1994 年が $9111 \mathrm{~km}^{2}$ に対して 2000 年 が 9447 km²で約 1.04 倍となった. このことから, 農業可 能面積が大きいことも, 2000 年の方の便益の高くなった 要因と言える.

栄養塩の履歷について，今回は考慮しなかった. もし 考慮すれば, 年々の堆積が, 次年に影響を与えるため, 違った結果が得られるかもしれない，しかしながら，今 回は 2000 年と 1994 年をシミュレートし, 対象年が離れ ているため考虑する必要はないと考えた。

堀はメコン河の氾濫について，大きな便益をもたらす 
ものではないと述べている の. しかし，この数值結果を 見ると地域間で差があり, 必ずしも汇濫が肥沃化に寄与 していないとは言いがたい.この問題については，現地 観測等によって明らかにする予定である.

\section{（4）対象地域での便益と損害について}

表 2 は, 計算対象地域で 2000 年と 1994 年の便益を比 較し,さらに 2000 年の損害額を示したものである. この 結果から, 大洪水により増加した 2000 年の便益は, 第 2 期農業の損害を補うほどに高いことがわかる.つまり, 大洪水は, 現時点で正の価值を増幅し, その一方で負の 価値を生じさせる対極な性質を持った存在であるといえ る.

しかしながら, 2000 年の大洪水は, 通常よりも早期に モンスーンが到来し, 中・上流域で例年よりも早く雨季 が始まったことが原因とされている ${ }^{1)}$. よって, その情 報を活用することで，今後起こりうる大洪水に対しての 開発マニュアルが作成されれば, 2000 年のような大損害 は生じることなく, 大洪水の利点だけが強調される結果 に代わると考えられる.

\section{（5）現地との比較}

図8で示した 2000 年第2期農業の損害シミュレーショ ンについて, 現地の考察と比較する. 土木学会報告書 ${ }^{1}$ によると, 農業関連は, プレイベン州, タケオ州, バッ タンバン州で被害を被ったとしている. バッタンバン州 は計算対象地域外であるが，メコン河下流域の左岸であ るプレイベン州で被害が生じたことは，本研究のシミュ レーションからも理解できる. しかし, シミュレーショ ンではスバイリエン州やコンポンチャム州で多大な損害 が生じているが，そのような報告はない．また，メコン 河とバサック川に挟まれた地域では，計算結果によると 農業・漁業ともに便益は高い。しかし，実際には人はあ まり住んでおらず便益は小さい，これは，氾濫期間が長 いことと冠水時の水位が高すぎることに由来している.

検証した結果, シミュレーションと実地情報とが異な る理由として, USGS の標高データでは表せないほどの 小さな土地の起伏もしくは特徴を利用して居住する場合 が多いことや人口分布を表す正確なデータが存在しない ことが挙げられる.

しかし, 本研究のシミュレーションと, 実際の収穫量 および土地利用を表現させることを今回は目的とはして いない. 本研究で重要な点は, 各メッシュにおけるポテ ンシャル,つまり農業およひ漁業の潜在能力を汇濫面積, 湛水継続期間および栄養塩指標を用いて表したことであ る.メッシュ区画で比較することを可能とした上で，今 後, 他産業を合めた比較を行うここが出束る.

\section{7. まとめ}

本研究では, 2000 年と 1994 年の洪水汇濫を精度良く 比較し，便益と損害を定量化することが出来た.

洪水を制御すれば，汇濫水，土砂や栄養塩が自然に供 給されるというメリットを失い，設備や肥料などの高い コストを要する. また, 汇濫原での水産業の便益は減少 する. したがって, 洪水の価值は正であると言える. し かし，ここで得られた結論は農業と水産業に限られたも ので, 今後は現地調查と解析によって工業, 教育や衛生 等の効果を検討したより総合的な評価が必要であると考 えられる.

謝辞 : 本研究を遂行するに際しては, 科研費(若手 $\mathrm{B}$ ，代 表:風間聡)の研究助成をいただいたことを付記し 謝意を表します。

\section{参考文献}

1) 土木学会水理委員会 : メコン河洪水氾濫調査 2000 年 11 月, 84pp, 2001.

2) Baran,E.,N.V.Zalinge and N.P.Bun,Floods,floodplains and fish production in the Mekong Basin:Present and past trend,Proc.Asian Wetlands Symp,pp.1-11,2001.

3) 風間 聡, 森杉壽芳, 沢本正樹 : 便益計算を用いたメ コン河洪水汇濫総合評価の試み, 水工学論文集, 第 47 巻, pp367-372, 2003.

4）建設省河川局: 治水経済調査マニュアル, 81pp,2000.

5) Mekong River Commission, LOWER MEKONG HYDROLOGIC YEARBOOK 1994.

6) 场博，メコン河 開発と環境，古今書院，1996.

7) Mekong Watch Japan : http://www.mekongwatch.org/

8) Puy Lim, Sovan Lek, Seang Tana Touch, Sam-Onn Mao and Borin Chhouk : Diversity and spatial distribution of freshwater fish in Great Lake and Tonle Sap river (Cambodia, Southeast Asia), Aquatic Living Resources, Volume 12, Issue 6, pp379-386, 1999

9) (財)矢野恒太記念会編集, 世界国勢図会, 国勢社, 1999.

10）片山精一郎，風間聡，蘇保林，沢本正樹 : 釜房ダム 流域における栄養塩の流出, 水工学論文集, 第 46 巻, pp223-228, 2002.

11) 山田 登, 東南アジアの稲作, 農政研究センター, 1978.

(2003.9.30 受付) 